\title{
THE EFFECT OFADDITIONAL CORN HUSK TOWARD THE MECHANICAL PROPERTIES OF LIGHT BRICK
}

\author{
Noer Af'idah ${ }^{1}$, Oktaffi Arinna Manasikana ${ }^{2}$, Andhika Mayasari ${ }^{3}$ \\ 1,2,3 Universitas Hasyim Asy'ari \\ Jombang, 61471, Indonesia \\ ${ }^{1}$ noerafidah1985@gmail.com, ${ }^{2}$ changemaker.salatiga@gmail.com, ${ }^{3}$ andhikamayasari@gmail.com
}

Accepted: October 15, 2020

Published: October 31, 2020

DOI: https://doi.org/1921107/jps.v7i2.8466

\begin{abstract}
The Light brick is an engineered product developed from the usual brick with the addition of mixed materials. Brick is one type of composite material. Many people choose to use natural fiber-reinforced composites to replace synthetic ones and composite materials engineering development. So in the technology of brick-making, natural fibers are currently used as a choice as additional material mixed to produce light bricks. Additional materials often used in light bricks include fly ash, sawdust, coconut husks, rice husks, etc. This study used corn husk waste as additional material in the light bricks making. The addition of corn husk powder can affect the mechanical properties of brick. It is shown by the more significant the percentage of corn husk powder added, the smaller the density and compressive test value of the brick produced. Meanwhile, the greater the porosity value is. The decrease in density level and compressive test value will undoubtedly affect the brick's mechanical and physical properties. The reduction in density level and mechanical properties of the brickwork can be minimized by applying an outer layer in the form of cement mortar of the products.
\end{abstract}

Keywords: Light Bricks, Composite, mechanical properties, Corn Skin.

\footnotetext{
${ }^{1}$ Corresponding Author
} 


\section{Introduction}

Waste is the residual material from a processing or production process both on a household and industrial scale. One of them is corn husk waste, which is produced from corn plants. So far, the abundant amount of corn husk waste has not been accompanied by the maximum efforts to process it. Cornhusk waste is only used as cattle or goat food, raw materials for handicrafts (such as decorative flowers, bag accessories, and wrapping paper), or most recently as raw material for making plastic (Faesal, 2013). Actually, the utilization of corn husk waste is not limited to those. It is necessary to think of how to use the waste corn husk into a higher value product.

This research attempts to utilize the corn husk waste into a high-value product and can be easily processed by the community. The researchers tried to use corn husk waste as a mixture to make brick composites produce highvalue light bricks.

Based on the General Requirements for Building Materials in Indonesia (PUBI 1982) article 6, "Brick is a type of stone made by printing and pressing method and is kept in a moist condition. Meanwhile, Frick Heinz and Koesmartadi argued that "Brick is a type of rock made without going through the combustion process." Brick is a type of composite material, a combination of two or more materials with different properties and characteristics.

Recently, bricks have become the building material for Indonesians' walls to replace conventional stones (Sumaryanto, 2009). Brick is preferable because it is easier to install and saves the cost of the building. However, behind all the advantages, bricks have several weaknesses. One of these is that the mass per cubic meter is quite large to affect the building structure's dead load. Those dead loads can be minimized by reducing the brick's mass, thus using light materials as a mixture in making the brick. Many various ways can be done to overcome. One of them is using alternative materials like the use of waste from organic and inorganic materials. Cornhusk waste is one type of organic waste which has not been utilized optimally until now. It can be used as an alternative material mixed in making bricks produce light bricks that are ready to use.

Several studies have been conducted related to the making of light bricks that use organic waste, such as waste from rice husks, bagasse ash, and sawdust. The addition of organic waste in the making of brick resulted in a greater percentage of the addition of the organic waste proportion in the mixture. The brick has a lighter mass, but in fact, the strength obtained becomes lower. (Aris, 2014). Therefore, in this study, corn husk waste was carried out to produce bricks with a light mass and tried to increase the mechanical strength by utilizing composite technology, thus coating the brick outside using a mixture of cement sand (cement mortar). This research is expected to produce a strong light brick.

Composite is a material formed from a combination of two or more constituent materials through an inhomogeneous mixture, where the properties of each material are different. Its mechanical properties and characteristics are others from its constituent materials. Basically, a composite can be interpreted as a material that microscopically consists of matrix and fibers as a filler (reinforcement). In general, physical filler materials have stronger properties than the matrix, so that the addition of this filler can increase the tensile strength value of the composite material. In contrast, the matrix itself plays a role in protecting the filling from environmental effects and damage due to collisions (Christian, 2010). In the bricks, the matrix's role is sand, which dominates the brick's volume, while cement and other mixed materials act as reinforcement or filler.

\section{Research Method}

In this research, these tools and materials include brick molding tools, knives, cement mixer, sand sieve, scale, cement, sand, water, and corn husk powder. The sample preparation was carried out by mixing corn husk powder, cement, sand, and water. After being mixed evenly, then molding and pressing the brick composite are processed using a solid method. The mold container is a cylinder with a diameter and a height of $5 \times 10 \mathrm{~cm}$. The process of drying the brick sample is by using the sun for approximately 28 days. In making these bricks, it used composite technology. Those are the technique of mixing or combining two or more types of materials with a specific purpose. This research aims to produce a mixed product in light bricks but has good quality and mechanical properties. 


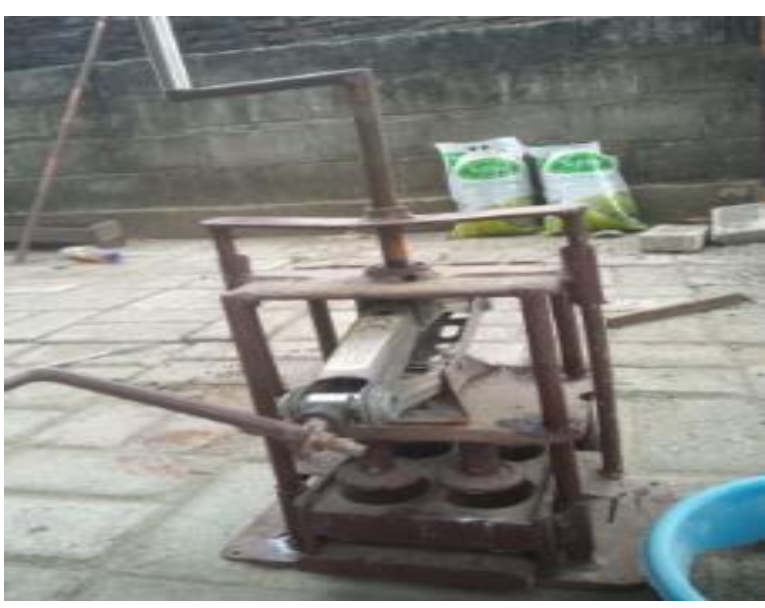

Figure 1. The ricks molding tool

Table 1. The composition variation of corn husk powder on the brick sample

\begin{tabular}{|c|c|c|c|c|}
\hline $\begin{array}{l}\text { Sample } \\
\text { code }\end{array}$ & $\begin{array}{l}\text { Cement } \\
(\%)\end{array}$ & $\begin{array}{l}\text { Cornhusk } \\
(\%)\end{array}$ & $\begin{array}{l}\text { Without } \\
\text { mortar } \\
\text { layer }\end{array}$ & $\begin{array}{l}\text { With } \\
\text { mortar } \\
\text { layer }\end{array}$ \\
\hline $\mathrm{S}_{20} \mathrm{~J}_{0} \mathrm{~T}$ & 20 & 0 & $\sqrt{ }$ & - \\
\hline $\mathrm{S}_{20} \mathrm{~J}_{10} \mathrm{~T}$ & 20 & 10 & $\sqrt{ }$ & - \\
\hline $\mathrm{S}_{20} \mathrm{~J}_{20} \mathrm{~T}$ & 20 & 20 & $\sqrt{ }$ & - \\
\hline $\mathrm{S}_{20} \mathrm{~J}_{30} \mathrm{~T}$ & 20 & 30 & $\sqrt{ }$ & - \\
\hline $\mathrm{S}_{20} \mathrm{~J}_{40} \mathrm{~T}$ & 20 & 40 & $\sqrt{ }$ & - \\
\hline $\mathrm{S}_{20} \mathrm{~J}_{50} \mathrm{~T}$ & 20 & 50 & $\sqrt{ }$ & - \\
\hline $\mathrm{S}_{20} \mathrm{~J}_{0} \mathrm{M}$ & 20 & 0 & - & $\sqrt{ }$ \\
\hline $\mathrm{S}_{20} \mathrm{~J}_{10} \mathrm{M}$ & 20 & 10 & - & $\sqrt{ }$ \\
\hline $\mathbf{S}_{20} \mathbf{J}_{20} \mathbf{M}$ & 20 & 20 & - & $\sqrt{ }$ \\
\hline $\mathrm{S}_{20} \mathrm{~J}_{30} \mathbf{M}$ & 20 & 30 & - & $\sqrt{ }$ \\
\hline $\mathrm{S}_{20} \mathrm{~J}_{40} \mathrm{M}$ & 20 & 40 & - & $\sqrt{ }$ \\
\hline $\mathrm{S}_{20} \mathrm{~J}_{50} \mathrm{M}$ & 20 & 50 & - & $\sqrt{ }$ \\
\hline $\mathrm{S}_{30} \mathrm{~J}_{0} \mathrm{~T}$ & 30 & 0 & $\sqrt{ }$ & - \\
\hline $\mathrm{S}_{30} \mathrm{~J}_{10} \mathrm{~T}$ & 30 & 10 & $\sqrt{ }$ & - \\
\hline $\mathrm{S}_{30} \mathrm{~J}_{20} \mathrm{~T}$ & 30 & 20 & $\sqrt{ }$ & - \\
\hline $\mathrm{S}_{30} \mathrm{~J}_{30} \mathrm{~T}$ & 30 & 30 & $\sqrt{ }$ & - \\
\hline $\mathrm{S}_{30} \mathrm{~J}_{40} \mathrm{~T}$ & 30 & 40 & $\sqrt{ }$ & - \\
\hline $\mathrm{S}_{30} \mathrm{~J}_{50} \mathrm{~T}$ & 30 & 50 & $\sqrt{ }$ & $\sqrt{ }$ \\
\hline $\mathrm{S}_{30} \mathrm{~J}_{0} \mathrm{M}$ & 30 & 0 & - & $\sqrt{ }$ \\
\hline $\mathrm{S}_{30} \mathrm{~J}_{10} \mathrm{M}$ & 30 & 10 & - & $\sqrt{ }$ \\
\hline $\mathrm{S}_{30} \mathrm{~J}_{20} \mathrm{M}$ & 30 & 20 & - & $\sqrt{ }$ \\
\hline $\mathrm{S}_{30} \mathrm{~J}_{30} \mathrm{M}$ & 30 & 30 & - & $\sqrt{ }$ \\
\hline $\mathrm{S}_{20} \mathrm{~J}_{40} \mathrm{M}$ & 30 & 40 & - & $\sqrt{ }$ \\
\hline $\mathrm{S}_{20} \mathrm{~J}_{50} \mathrm{M}$ & 30 & 50 & - & $\sqrt{ }$ \\
\hline
\end{tabular}

The sample of this study was made by several variations in the composition of the components. It is used to determine which brick samples have the best characteristics. This study used a variation cement of $20 \%$ and $30 \%$ of the brick sample's total volume. While variations in the composition of corn husk powder are made from variations of $10 \%, 20 \%, 30 \%, 40 \%$, and $50 \%$. As a standard, samples of bricks were also made without the addition of corn husk powder.

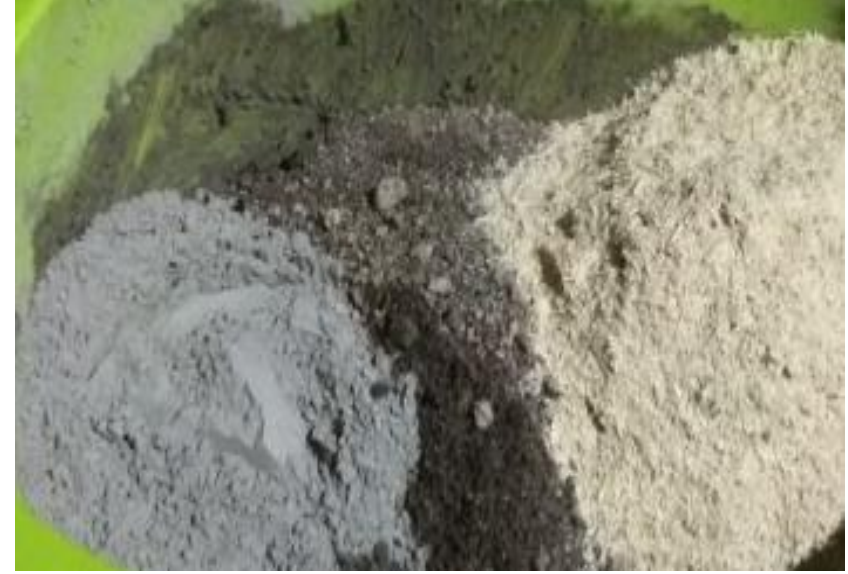

Figure 2. The corn husk powder, cement, and sand

The bricks from various compositions are made with and without cement mortar coating. The variation of the bricks sample is explained in table 1.

This research was conducted by utilizing corn husk waste in the form of fine powder. Cornhusk powder was obtained from the UPT Materia Medica Herbal Laboratory, Batu City, Malang. The sample preparation is done by mixing all the ingredients and adding a little water. The brick is usually made with a mixture of cement and sand. In this study, corn husk powder was added to reduce the brick's mass, so it is expected that the resulting brick is lighter in mass than the conventional brick. The cement itself has a function as a binder in the brick composite. After all, the ingredients are mixed evenly, put it in a brick molding tool, and let it stand for about 15 minutes. The new brick is ready to be tested and characterized after heating for 28 days. According to Tjokrodimulyo, cement can reach the greatest level of hardness at the age of 28 days. This can be seen from the color change in the sample from dark gray to white. (Tjokrodimulyo, 1995).

The brick's mechanical and physical properties' characterization was carried out by testing the density, porosity, and compressive test on the brick sample. The measurement of the density value is carried out to determine the density level of the resulting sample. The density measurement weighs the brick's mass, dried for 28 days, and measuring its volume. The ratio of mass with the bricks' volume shows the density value of the resulting sample. The greater the density value of a sample, the better the quality of the brick produced.

$$
\rho=\frac{\operatorname{massa}(\mathrm{Kg})}{\operatorname{Volume}(\mathrm{m})^{3}}
$$


The sample's porosity test is carried out by immersing the dry sample in water for 24 hours until it is absorbed into all the pores. Furthermore, the wet sample is weighed using a digital balance. The percentage of water absorption is formulated as follows:

$$
\mathrm{P}(\%)=\left(\left(\mathrm{M}_{\mathrm{b}}-\mathrm{M}_{\mathrm{k}}\right): \mathrm{M}_{\mathrm{k}}\right) \times 100 \%
$$

Explanation:

P : Absorption Percentage (\%)

$\mathrm{M}_{\mathrm{b}}$ : Wet Brick Mass (gr)

$\mathrm{M}_{\mathrm{k}}$ : Dry Brick Mass (gr)

The characterization of the compressive strength test was carried out by pressing the sample until destroyed. The efficiency itself is the unit area press's value that causes the test object to be destroyed when given a compressive force. The compressive strength test is pressed after the brick has been dried for 28 days.

\section{Result and Discussion}

The following is a light brick sample with corn husk powder before and after drying for 28 days. The brick has been dried for 28 days is characterized by a color-changing from dark gray to light gray to white. It shows that the cement has reached a maximum hardness level. In dried samples, the more volume of corn husks added, the more yellowish-brown the color is.

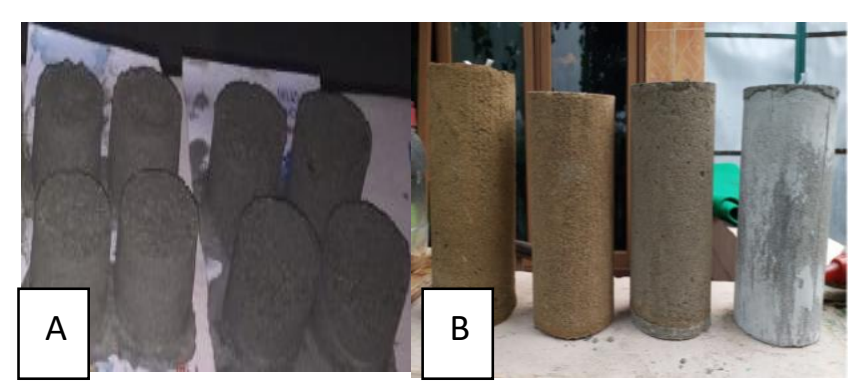

Figure 3. The brick sample before $[\mathrm{A}]$ and after drying [B]

The light brick is characterized to determine how the effect of adding corn husks powder to the mass load of the brick, the compressive test value, the density, and the porosity. From the research conducted by Aris Pratama in 2014, light brick composites utilizing rice husk waste obtained results that the greater the composition of rice husks added, the lighter the bricks produced. However, the density and strength values of the brick are getting smaller. In this study, the variations of brick samples were made without cement mortar and samples with additional cement mortar outside. With the addition of a layer of cement mortar outside the brickwork, it is hoped that it can reduce the value of the decrease in density and strength of the resulting brick.

Figure 4 shows that the more corn husk powder is added, the smaller the bricks' mass value. It means that the greater the percentage of corn husk powder used, the lighter the resulting brick. From the graph, it can also be stated that in general, the mass of bricks with cement volume of $20 \%$ is lighter in mass when it is compared to $30 \%$ of cement bricks. The smaller the brick's mass, the lighter the dead load that the structure must accept in a building.

The light brick samples' compressive strength test was carried out at the Civil Engineering Laboratory of the Hasyim Asy'ari Tebuireng University, Jombang. The efficiency of tTheessive shows-1979-F is the amount of load per unit area that causes the object or test sample to buoyed when being press by a compressive force. The pressure applied to the brick's mass large so that the light brick sample will crack alight brick samples' and then crumble. In figures of the compressive test on light brick with the corn husk powder. The compressive strength range's value is between $0 \%$ to $50 \%$ of the sample material's total volume was $8.1 \mathrm{MPa}-14.7 \mathrm{MPa}$. The compressive strength value decreases along with the increase in the percentage of corn husk powder used. The greater the amount of corn husk powder, the more porosity distribution in the block. The reduction in the amount of sand brick will reduce the block's ability to withstand plastic deformation. This is indicated by a decrease in the compressive strength value of the brick sample. The material's porosity causes the density between particles to get smaller, even though the density is one of the most important properties for the bonding between particles. The higher the density, the better the strength of the brick (Widarmana, 1979 and Zakaria, 1996).

Figure 6 shows that the greater the percentage volume of corn husk powder added to the sample, the smaller the density value. The brick with a cement percentage of $30 \%$ has a better density value than those of $20 \%$ by volume of cement. The more cement that is added, the greater the bonds between the particles making up the brick. It is also because basically, the cement functions as a binder of the particles of the brick. The greater the bonds between the particles, the greater the density of the material. The greater the brick's density value, the greater the physical and mechanical properties of the brick. 
The Effect of Additional Com Husk Toward The Mechanical Properties Of Light Brick

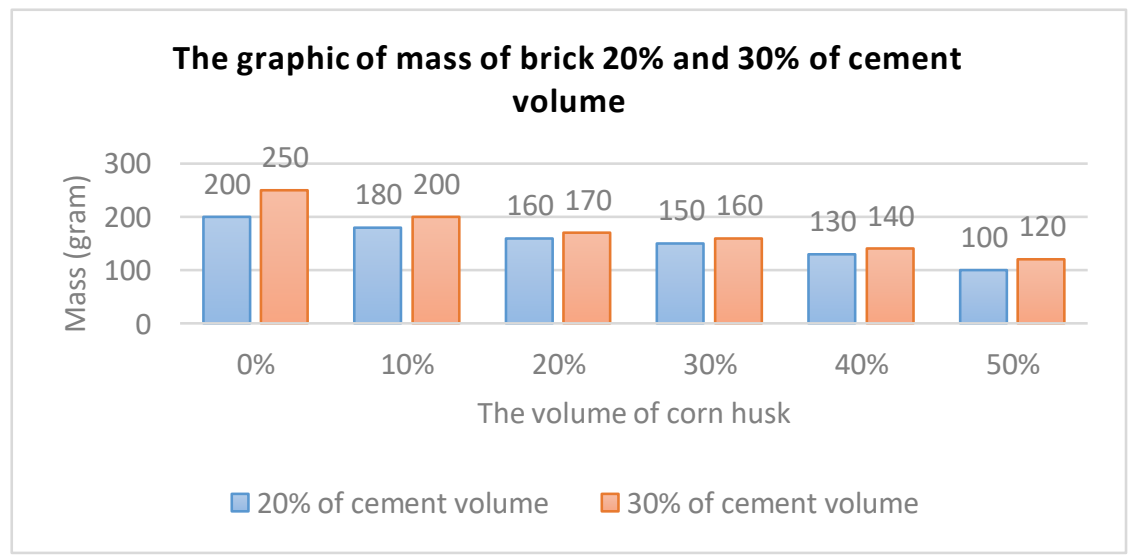

Figure 4. The graphic of bricks $20 \%$ and $30 \%$ of cement volume

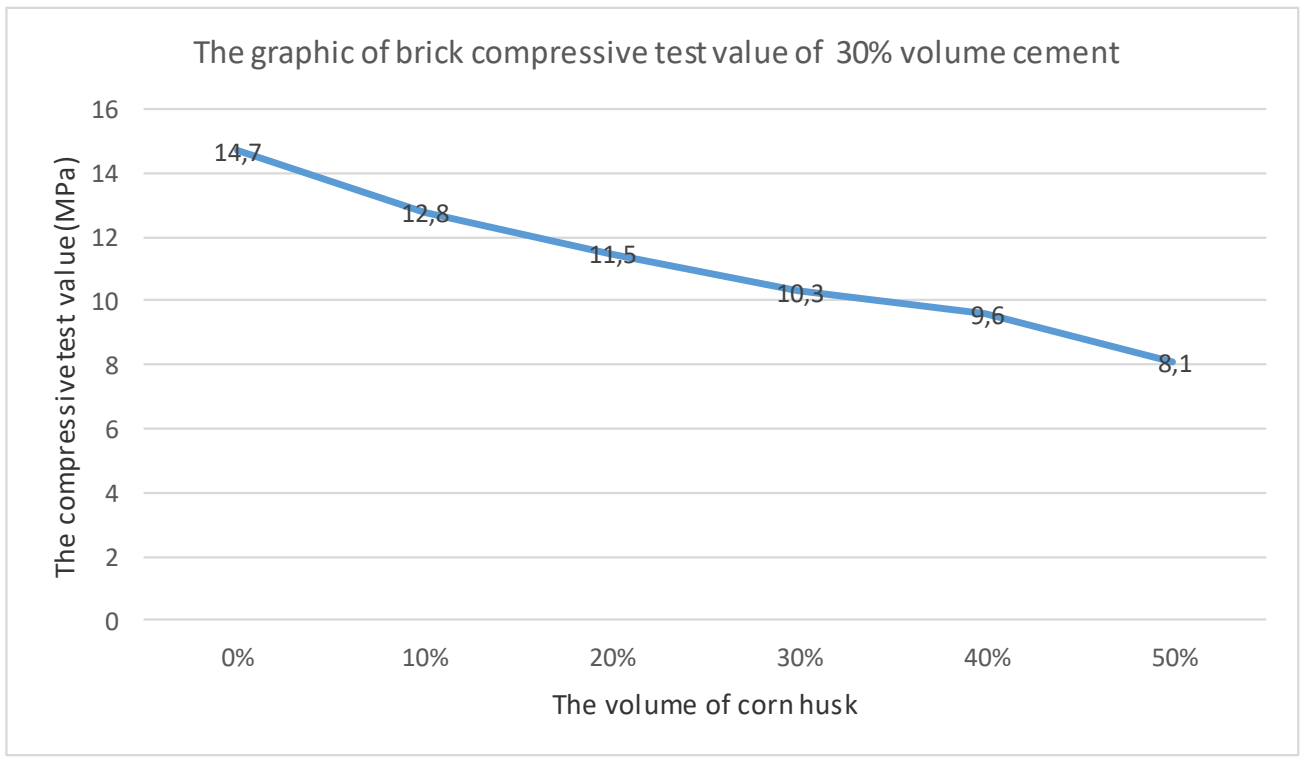

Figure 5. The graphic of bricks compressive test value of $30 \%$ cement volume

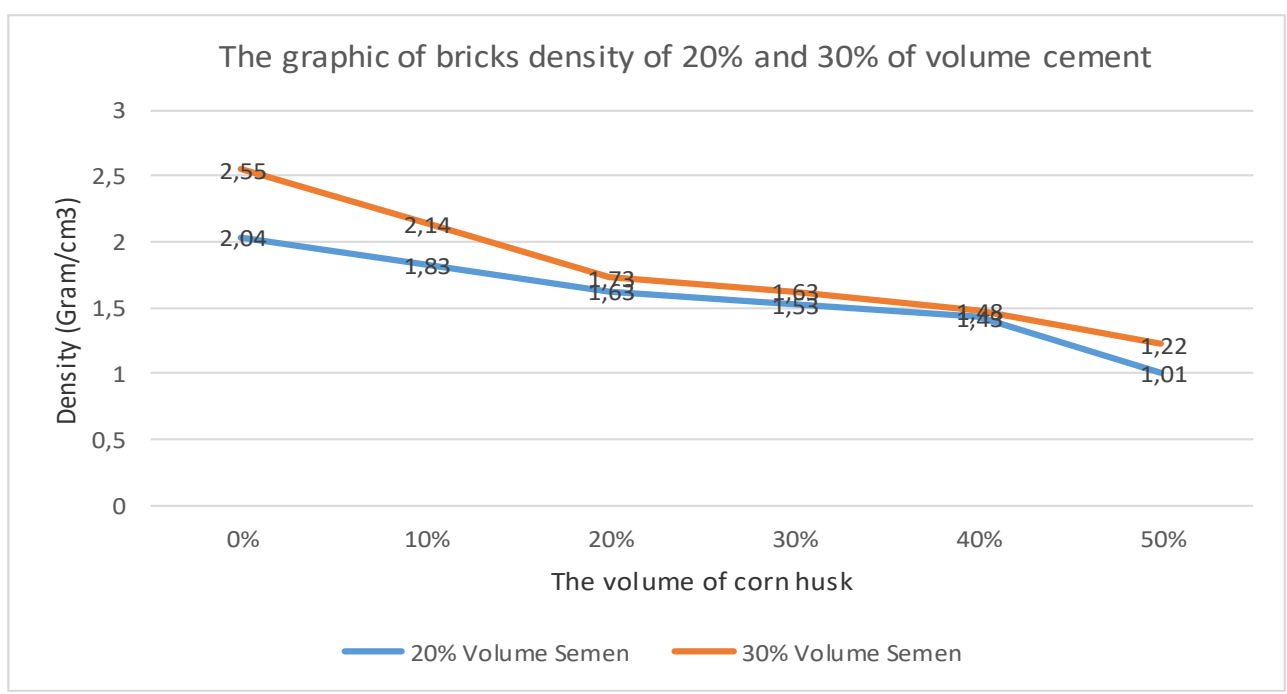

Figure 6. The graphic of bricks density of $20 \%$ and $30 \%$ of volume cement 


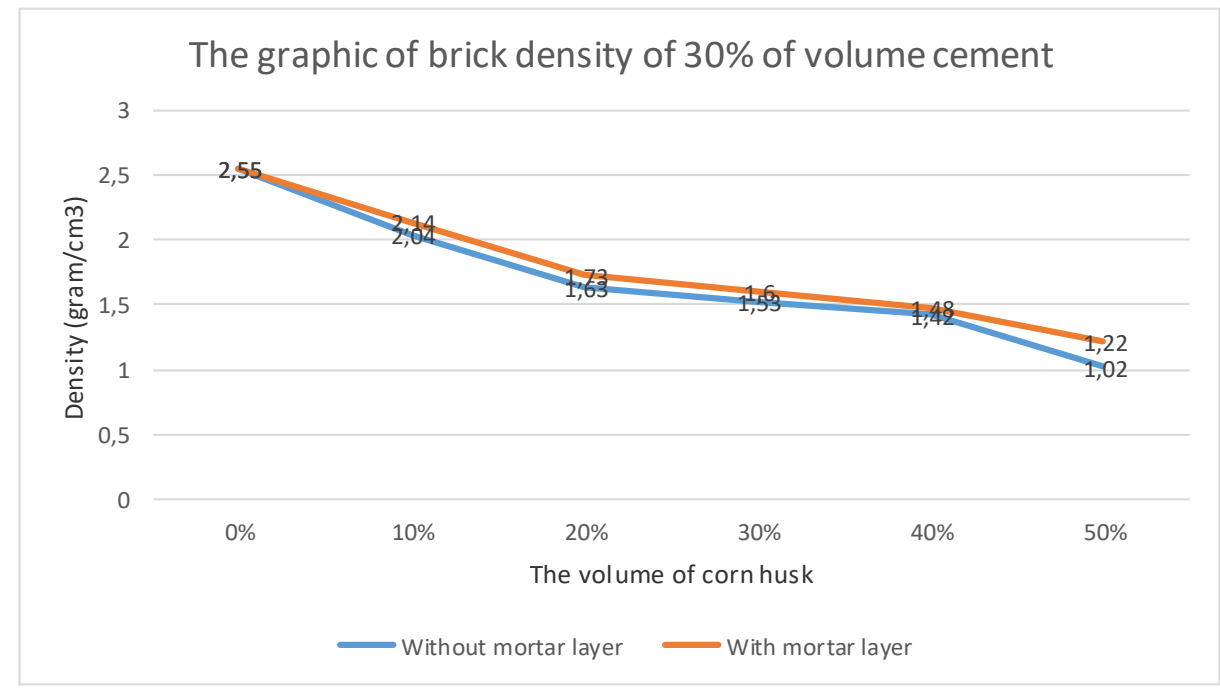

Figure 7. The Graphic of the brick density of $30 \%$ of volume cement with and without mortar layer.

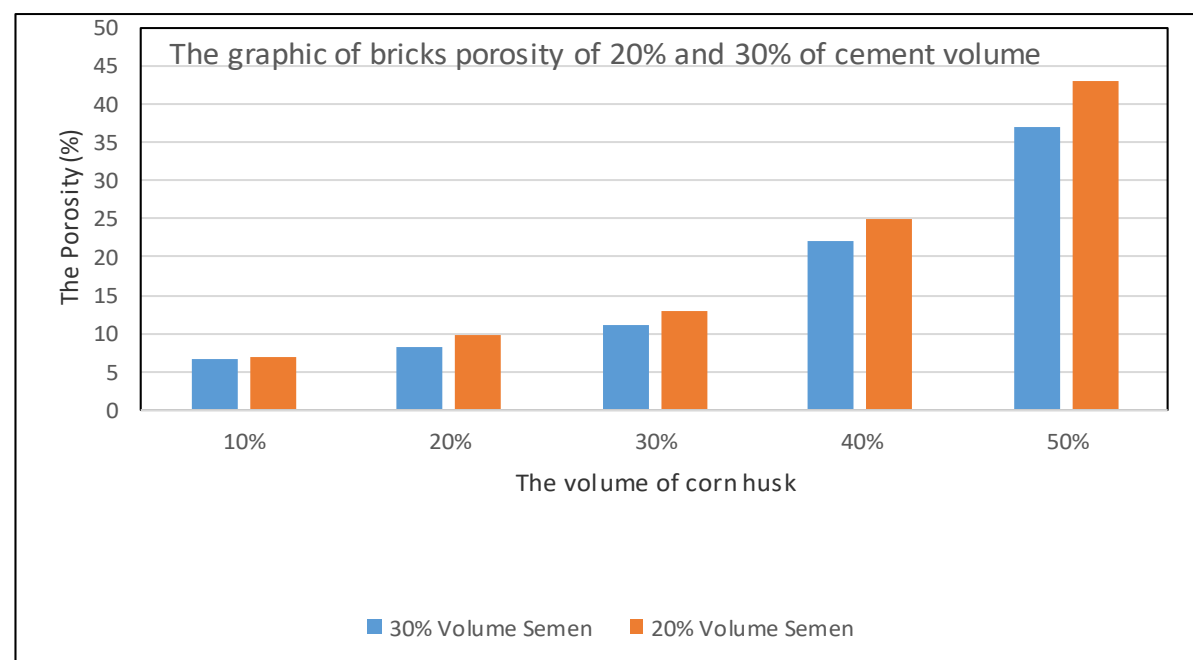

Figure 8. The Graphic of bricks porosity of $20 \%$ and $30 \%$ of cement volume

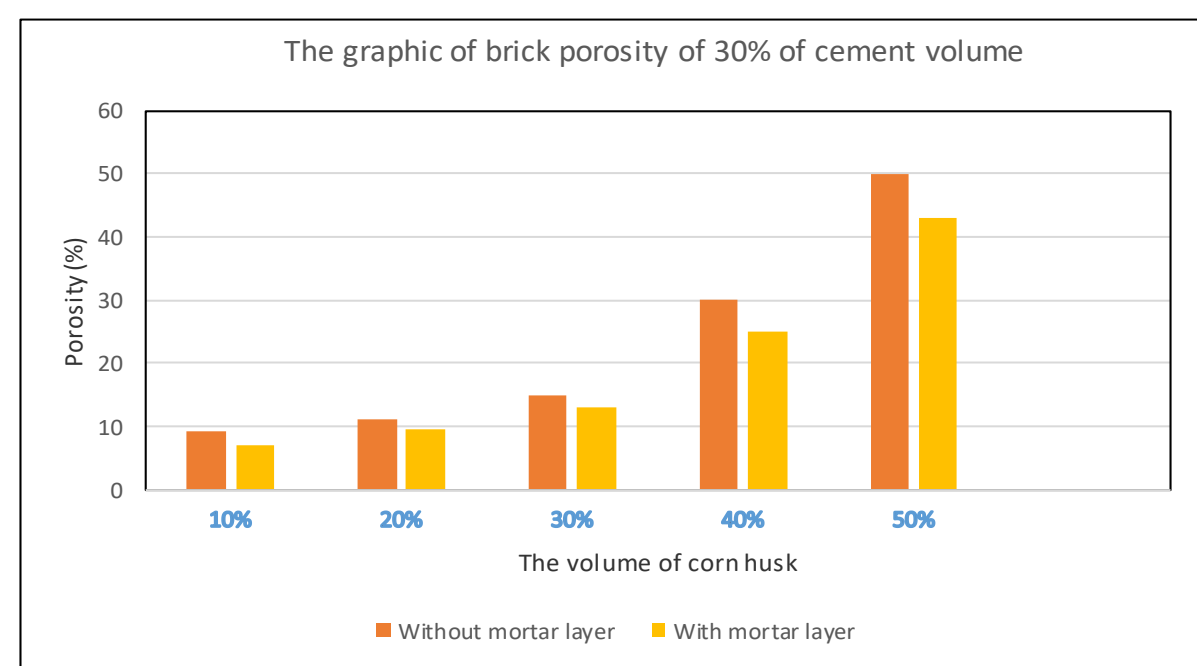

Figure 9. The graphic of brick porosity of $30 \%$ of cement volume with and without mortar layer 
Figure 7 shows that adding a layer of cement mortar to the outside of the brick can reduce the brick's density value. Although the sample's density value without mortar layer or with the mortar layer is not much different, at least the addition of the mortar layer of the cement can increase the bond between the particles, even though only on the outside of the sample.

The testing of the porosity level of the brick sample's porosity is carried out to determine the amount of empty space or small pores in the brick sample. The porosity test was carried out by weighing the sample in a dry condition $\left(\mathrm{m}_{\mathrm{k}}\right)$. The sample is then immersed in the water until all parts of the sample are immersed for 24 hours. The function of soaking it for 24 hours is to give the water a chance to fill the small pores or empty spaces. After being immersed for 24 hours, the sample was then weighed to determine the sample's wet mass $\left(\mathrm{m}_{\mathrm{b}}\right)$. The difference between the wet mass and the sample's dry mass is compared to the dry mass, then multiplied by $100 \%$. Then, the sample's porosity value will be obtained.

From Figure 8 above, it can be concluded that generally, the porosity value of the brick sample is getting bigger along with the increase in the percentage of corn husks added. The sample's average porosity value with the volume of cement was $30 \%$ smaller than those of $20 \%$. The cement can bind the particles that make up the material. The greater the cement volume, the stronger the bonds between the constituent particles and the smaller the distance between the particles. So that the number of empty spaces or air cavities is also getting smaller. The sample with the greatest porosity value is the sample volume of $20 \%$ cement with $50 \%$ corn husk powder. The greater the porosity value of a material, the greater the level of material fragility. It can be explained that if the porosity of the material is high, there will be more air voids or empty space in the material. This causes the distance between particles to be further away so that the bonds between particles are getting smaller. If the bonds between particles are small, then the material is easy to break, or it can be said that the physical and mechanical properties are low. It can be seen again in Figure 5 above. In a sample with a cement volume of $30 \%$, the more volume of corn husks added, the smaller the value of the sample's compressive strength. The smaller the compressive strength value of a material, the smaller the material's mechanical properties are.
The size of the brick's water absorption is significantly influenced by the pores or cavities contained in the brick. The water absorption test here is carried out to determine the porosity value of the resulting brick material. The greater the brick's porosity value, the greater the volume of water absorbed by the brick so that the durability or strength of the brick can decrease. The porosity contained in the brick is formed due to the lack of bonds between the constituent particles, causing the formation of air cavities in the brick. The smaller the porosity value of the brick, the better the quality of the brick produced. Figure 9 shows that the brick sample's level of porosity given a cement mortar layer is smaller than that of the brick sample without a cement mortar layer. It can be explained that the porosity measurement method uses water absorption by the composite when the surface of the composite is coated by cement mortar, so the water absorbed by the composite will be blocked by cement mortar.

\section{Conclusion}

The addition of corn husk to the brick composite can produce light bricks. However, the greater the percentage of corn husk powder added, the smaller the brick's compressive test and density value. On the other hand, the concrete blocks' porosity value is getting bigger, along with the increasing percentage of added corn husks. The decrease of the compressive test and density value and the increase of the brick porosity value causes a reduction in the brick-produced level of physical and mechanical properties. The addition of a cement mortar layer can reduce the decrease in the resulting brick's physical and mechanical properties.

\section{References}

Aris, P. (2014). Pembuatan dan karakterisasi komposit batako ringan dengan campuran sekam padi sebagai bahan pengisi untuk konstruksi bangunan redam suara, Jurusan Fisika FMIPA, UNILA, Lampung.

Chrishtian, P. (2010). Kajian Kekuatan Komposit Sekam Padi Sebagai Pembuat Bumper Mobil. Skripsi Universitas Diponegoro, Semarang.

Faesal. (2013), Pengolahan Limbah Tanaman Jagung untuk Pakan Ternak Sapi Potong. 
Prosiding Seminar Nasional Inovasi Teknologi Pertanian, Badan Litbang Pertanian, Jakarta.

Frick, H. (1996), Arsitektur dan Lingkungan. Yogyakarta. Kanisius.

Persyaratan Umum Bahan Bangunan Indonesia (PUBI) 1982 PASAL 6, tentang batu cetak beton (batako).

Sumaryanto, D, et al. (2009), Batako Sekam Padi Komposit Mortar semen, Jurusan Teknik Sipil, UGM, Jogjakarta.

Sarowa'a, Y. (2018), Pengaruh Abu Ampas Tebu Sebagai Bahan Subtitusi Semen Pada Pembuatan Batako, Fakultas Tekik Sipil, Universitas Negeri Medan, Medan.

Tjokrodimulyo, K. (1995). Buku Ajar Bahan Bangunan. Yogyakarta: Jurusan Teknik Sipil. Teknik Universitas Gajah Mada.

Widarmana S. (1977). Panil-panil Berasal dari Kayu Sebagai Bahan Bangunan. Prosiding Seminar Persaki di Bogor 23-24 Juni. Bogor. 